\title{
ENGAGING CUSTOMERS ON FACEBOOK COFFEE SHOPS' BRAND-FAN PAGES
}

\author{
Lucia Ferencakova \\ Faculty of Management, Comenius University in Bratislava, Bratislava, Slovak Republic \\ Email: lucia.ferencakova@,fm.uniba.sk \\ Krzysztof Gajdka \\ University of Entrepreneurship and Law Prague, Czech Republic \\ Email: krzysztof.gajdka@,vspp.cz \\ Vaclav Netek \\ University of Entrepreneurship and Law Prague, Czech Republic \\ Email: vaclav.netek@vspp.cz \\ Pavel Kapoun \\ University of Entrepreneurship and Law Prague, Czech Republic \\ Email: pavel.kapoun@vspp.cz
}

Received: 2 May 2020. Revision received: 31 May 2020. Accepted: 3 June 2020

\begin{abstract}
Social media's importance is increasing rapidly in the business world as in the lives of individuals (Bitiktas et al., 2020). Thus, customer engagement (CE) in co-creating customer experience and value is receiving increasing attention from business practitioners and academics alike (Brodie, 2011). The study aims to examine content strategy on coffee shops' Facebook brand-fan pages in terms of differences in the length of the text part of the posted content and its impact on customer engagement. Using the Fanpage karma web application, we collected a total number of 1254 of 10 coffee shops' brand-fan pages posts published on Facebook during the year 2019. We found that there is a statistically significant difference between text length according to post type (status, photo, video, link) ( $\mathrm{p}=0.0007)$, and also customer engagement differs depending on post type $(\mathrm{p}=0.0009)$. Surprisingly we also revealed that in text length, there is a statistically significant difference only between photo and status types of posts $(p-V a l u e=0.0009)$ and in customer engagement $(\mathrm{CE})$, only between the photo and video types of posts $(\mathrm{p}$-Value=0.0044). Results of linear regression also were not able to support hypothesis, that the shortest length of the text leads to higher customer engagement (CE). The study extends the research on customer engagement (CE) and expands the knowledge about the Facebook content strategy of coffee companies. Finally, it offers recommendations for future research in the examined area.
\end{abstract}

KEYWORDS: social, networks, Facebook, customer, engagement, content.

JEL CLASSIFICATION: M31, M370, M15.

Reference: Ferencakova, L., Gajdka, K., Netek, V. \& Kapoun, P. (2020). Engaging Customers on Facebook Coffee Shops' Brand-Fan Pages. International Journal of Entrepreneurial Knowledge, 8(1), 65-75. doi: 10.37335/ijek.v8i1.110

\section{INTRODUCTION}

Social networking is currently the most popular online activity worldwide (Kujur et al., 2017; Tulu, 2017). For instance, Facebook enables us to connect with friends and foster relationships with new ones (Tulu, 2017), which is also used by companies.

Thus, we as customers become easily accessible, even for small businesses, for which social networks have become a critical marketing channel for building relationships with customers (Gruss et al., 2020) 


\section{INTERNATIONAL JOURNAL OF ENTREPRENEURIAL KNOWLEDGE}

Issue 1, volume 8, ISSN 2336-2960 (Online)

www.ijek.org

and spreading marketing messages. Thus, marketing activities are now more inclined to social networks than ever before in the business (Rehman et al., 2020).

At the same time, companies try to find new ways of connecting and engaging us to their activities (Zeng et al., 2019) and therefore use the active management of social media presence (Miller et al., 2013) to establish and maintain a competitive advantage (Chan et al., 2014).

Although many researchers aimed to study the factors that impact customer engagement, and many different definitions of $\mathrm{CE}$ have been published in scholarly literature, a consensus in its conceptualization has not yet been reached (Dijkmans et al., 2015). However, the common element of most definitions of customer engagement is emphasizing just the increasingly active role of the customers (Javornik et al., 2012) and consider CE as an appropriate concept for analyzing their interactions with brands (Kumaresan, 2014). This study examines the content strategy on coffee shops' Facebook brand-fan pages and factors driving customer engagement (CE) to address the mentioned research gaps.

The paper is organized as follows. We first present short theoretical background literature on customer engagement in social networks domain. It is followed by the methodology section, which explains the research context, methods of data collection, and data analysis. After that, we discuss the results and their implications for marketing literature and practice. Finally, we conclude with some insights for future research.

\section{SHORT THEORETICAL BACKGROUND}

Social networks refer to "a group of Internet-based applications that build on the ideological and technological foundations of Web 2.0, and that allow the creation and exchange of user-generated content" (Kaplan et al., 2010). They contain highly unstructured data combining text, images, animations, and videos, which are useful in making the public aware of various issues (Ravi et al., 2015) and can pull in numerous to interface with others (Kujur et al., 2020).

Customer engagement (CE) can be defined as a motivational state that occurs through the interactive experience with brand content on social networks, and is expressed in the form of relevant cognitive (e.g., being interested in a company's activities), emotional (feeling positive about a company's activities) and/or behavioral (participation in the company's activities) practices (Avnet et al., 2018; Brodie, 2011; Dijkmans et al., 2015; L. Hollebeek, 2011; L. D. Hollebeek, 2011; Hollebeek et al., 2016). These practices are manifestations of customers' motivational states of brand engagement (the intrapersonal dynamics of brand engagement), namely cognitive (how much customers think about a brand), emotional (what people feel about a brand), and behavioral brand engagement (how much energy, effort, and time customers spend on using a brand) (Eigenraam et al., 2018).

In the Facebook environment, companies develop relationships with customers through messages accompanied with text, photos, or videos and other material (company's page content) (Vaičiukynaite et al., 2018). CE is manifested as liking, commenting, and sharing the company's page content (Gruss et al., 2020) and refers to a type of activity beyond purchasing (B. Kim et al., 2020). In essence, it actively leads customers to serve as pseudo-marketers for the company (Harmeling et al., 2016).

In this context, we consider sharing, in terms of the extent of involvement, as the highest form of engagement followed by commenting and liking (Bitiktas et al., 2020; Cho et al., 2014; Cooper et al., 2019; Swani et al., 2014). Higher active or passive customer participation (customer engagement) with contents at least leads to better spreading the company messages, create better customer experience (Chiang et al., 2018), by enhancing relationships (De Vries et al., 2014), and increasing customers' value (Ersoy et al., 2018). For coffee-shops, social networks are a particularly valuable reference for customers when choosing a venue (E. Kim et al., 2016) because of the intangibility of their services. 


\section{INTERNATIONAL JOURNAL OF ENTREPRENEURIAL KNOWLEDGE}

Issue 1, volume 8, ISSN 2336-2960 (Online)

www.ijek.org

Kim et al. (2020) reveal that information quality is the most important predictor of customer engagement (CE); therefore, restaurants need to mainly focus on providing high-quality information through their social networks. Posts should include videos and images because they have the highest positive impact on engagement (Bitiktas et al., 2020; Siyam et al., 2020). Furthermore, Vaičiukynaite \& Gatautis (2018) add that marketers should use more social messages and images with humans to increase the number of likes, comments, and emotional expressions and foster customer engagement (CE) on Facebook.

Gruss et al. (2020) also dealt with the posts' content using restaurants on Facebook. They found that appeals to a feeling of belonging to the community have a significant positive effect on customer engagement (CE) and confirmed that social network content should (1) contain photos and videos, (2) be posted earlier in the day, (3) be lengthy but written in simple language, (4) should not be a reference to another URL, and (5) should have a variety of content over the long term. Partially different are the Banerjee \& Chua (2019) findings that state that length of the posts is negatively related to engagement likely because Facebook only shows a fragment of long entries and users are required to click on an additional link to read the entire content.

It is also important to note that emotional appeals increase the engagement level (Bitiktas et al., 2020; Thongmak, 2015), while informative appeals do not drive customer engagement (Rietveld et al., 2020).

\section{AIM, METHODOLOGY, AND METHODS}

Social networks refer to "a group of Internet-based applications that build on the ideological and technological foundations of Web 2.0, and that allow the creation and exchange of user-generated content" (Kaplan et al., 2010). They contain highly unstructured data combining text, images, animations, and videos, which are useful in making the public aware of various issues (Ravi et al., 2015) and can pull in numerous to interface with others (Kujur et al., 2020).

The study aims to examine content strategy on coffee shops' Facebook brand-fan pages in terms of differences in the length of the text part of the posted content and its impact on customer engagement.

Based on the above short theoretical background, we formulated the hypotheses as follows:

- H1: Diverse content types (status, photo, video, link) of company posts on coffee shops' Facebook brand-fan pages differ in the length of the text part.

- H2: Diverse content types (status, photo, video, link) of company posts on coffee shops' Facebook brand-fan pages differ in engagement.

- H3: Shortest length of the text part (status, photo, video, link) of company posts on coffee shops' Facebook brand-fan pages leads to higher customer engagement.

Data Collection. We used Facebook to collect the data because it the most widespread (with $76 \%$ share) social network in Slovakia for any purpose (Newman et al., 2019). Using the Fanpage karma web application, we collected ten coffee shops' brand-fan pages posts published on Facebook during 2019. A total number of 1254 posts were selected for further investigation. According to the type of post: there were $62(4.94 \%)$ statuses (small amount of text published in Facebook news feeds), 1104 $(88.04 \%$ ) photos (usually picture of the company product, events or meme connect with small amount of text published in Facebook news feeds) 61 (4.86\%) videos (likewise as a photo), $27(2.15 \%)$ links (connections to select destinations published in Facebook news feeds, on or off Facebook-owned properties, for an example company website or e-shop). The average number of posts per one company was 125.4 (SD=125.13, Minimum=27, Median=99.5, Maximum=444). 
INTERNATIONAL JOURNAL OF ENTREPRENEURIAL KNOWLEDGE

Issue 1, volume 8, ISSN 2336-2960 (Online)

www.ijek.org

The average length of the text part of all posts (statuses, photos, videos, links) was 173.81 ( $\mathrm{SD}=133.21$, Minimum=0, Median=151, Maximum=1,113). If we exclude posts without text, the average length of the text part of all posts (statuses, photos, videos, links) was slightly different 189.04 ( $\mathrm{SD}=128.14$, Minimum=7, Median=161, Maximum=1,113).

On average, there were 24.24 interactions (Likes including Love, Haha, Wow, Sorry, Anger; Comments; Shares) per post $(S D=36.80$, Minimum=0, Median=13.5, Maximum=390). If we exclude posts without interactions ( 65 posts), the average number of interactions was 25.56 per post $(\mathrm{SD}=37.35$, Minimum=1, Median=15, Maximum=390).

To calculate customer engagement, we have adapted Rakhmawati et al. (2018) Engagement Index (Rakhmawati et al., 2018) according to findings of Bitiktas et al., 2020; Cho et al., 2014; Cooper et al., 2019; Swani et al., 2014, that sharing, in terms of the extent of involvement is the highest form of engagement followed by commenting and liking. Also, we have decided to distinguish simple Likes from Love, Haha, Wow, Sorry, Anger types of "Likes." We distinguished the individual reactions by the following coefficients: Likes=1; Love, Haha, Wow, Sorry, Anger=5; Comments=10; Shares=100. Subsequently, customer engagement was calculated as numbers of reactions (Likes in all forms, Comments, Shares) weighted with the coefficients mentioned above multiplied with the number of fans on the day of the post and divided by 1000 .

Analysis. Distributions of dependent variables (length of the text part of the post and customer engagement) were checked with the Anderson-Darling test of normality. The logarithms of the values were used in further analysis. We used the analysis of variance (ANOVA) to test the proposed hypotheses $\mathrm{H} 1$ and $\mathrm{H} 2$. Simple linear regression was used to predict the dependent variable values as a function of the independent variables (H3).

\section{RESULTS AND DISCUSSION}

Table 1 demonstrates the descriptive statistics of this study. Results suggest that there is a difference between text length according to post type. Surprisingly, this is not the status (Mean number of characters $=104.19$ ) that would have the longest text length, but the link (Mean number of characters $=210.96)$ followed by photo $($ Mean number of characters $=178.16)$.

\section{Table 1 The text length according to post type (untransformed data)}

\begin{tabular}{||c|c|c|c|c|c||}
\hline \hline TYPE & MEAN & STD DEV & MIN & MAX & MEDIAN \\
\hline link & 210.96 & 204.57 & 11 & 1065 & 167 \\
\hline photo & 178.16 & 129.95 & 0 & 1113 & 157.5 \\
\hline status & 104.19 & 89.34 & 0 & 414 & 98 \\
\hline video & 149.51 & 165.24 & 0 & 701 & 92 \\
\hline
\end{tabular}

(Source: Authors' Calculations)

According to H1, diverse content types (status, photo, video, link) differ in the length of their text part. As Table 2 presents, the differences between some of the means in text length are statistically significant $(\mathrm{p}=0.0007)$, and thus the results support $\mathrm{H} 1$.

Table 2 ANOVA results - the text length according to post type (log-transformed data) 
INTERNATIONAL JOURNAL OF ENTREPRENEURIAL KNOWLEDGE

Issue 1, volume 8, ISSN 2336-2960 (Online)

www.ijek.org

\begin{tabular}{|c|c|c|c|c|c|}
\hline LEVEL & NUMBER & MEAN & $\begin{array}{c}\text { STD } \\
\text { ERROR }\end{array}$ & F RATIO & $\mathrm{PROB}>\mathrm{F}$ \\
\hline link & 27 & 4.97018 & 0.12993 & \multirow[b]{4}{*}{5.6678} & \multirow[b]{4}{*}{0.0007} \\
\hline photo & 1028 & 5.05839 & 0.02106 & & \\
\hline status & 51 & 4.6919 & 0.09454 & & \\
\hline video & 47 & 4.88373 & 0.09848 & & \\
\hline
\end{tabular}

(Source: Authors' Calculations)

We also used the Tukey Simultaneous Test for finding differences in text length means in individual pairs of post types. As Table 3 presents, the only difference in photo-status text length is statistically significant $(\mathrm{p}-$ Value $=0.0009)$.

Table 3 Tukey Simultaneous Tests for Differences of Means - the text length according to post type (log-transformed data)

\begin{tabular}{||c|c|c|c|c|c||}
\hline \hline LEVEL & DIFFERENCE & $\begin{array}{c}\text { STD ERR } \\
\text { DIF }\end{array}$ & $\begin{array}{c}\text { LOWER } \\
\text { CL }\end{array}$ & UPPER CL & P-VALUE \\
\hline $\begin{array}{c}\text { photo - } \\
\text { status }\end{array}$ & 0.3664832 & 0.0968532 & 0.117293 & 0.6156728 & 0.0009 \\
\hline link - status & 0.2782737 & 0.1606813 & -0.135137 & 0.691684 & 0.3076 \\
\hline $\begin{array}{c}\text { video - } \\
\text { status }\end{array}$ & 0.1918218 & 0.1365099 & -0.159399 & 0.5430423 & 0.4963 \\
\hline $\begin{array}{c}\text { photo - } \\
\text { video }\end{array}$ & 0.1746614 & 0.1007033 & -0.084434 & 0.4337568 & 0.3062 \\
\hline photo - link & 0.0882094 & 0.1316233 & -0.250439 & 0.4268576 & 0.9083 \\
\hline link - video & 0.086452 & 0.1630309 & -0.333004 & 0.5059076 & 0.9517 \\
\hline
\end{tabular}

(Source: Authors' Calculations)

Table 4 shows the interactions descriptive statistics in absolute numbers. Results revealed that the customer mostly used the lowest form of involvement (Like) with posts. Also, they cannot identify very well with the published post because of the low share rate (Mean per post $=1.1$ ).

Table 4 Interactions (Likes, Love, Haha, Wow, Sorry, Anger, Comments, Shares) on posts (untransformed data)

\begin{tabular}{||c|c|c|c|c|c|c||}
\hline \hline $\begin{array}{l}\text { ANALYSIS } \\
\text { COLUMNS }\end{array}$ & SUM & MEAN & STD DEV & MIN & MEDIAN & MAX \\
\hline Likes & 25892 & 20.65 & 31.47 & 0 & 12 & 354 \\
\hline Love & 2156 & 1.72 & 3.22 & 0 & 0 & 28 \\
\hline Haha & 81 & 0.06 & 0.58 & 0 & 0 & 12 \\
\hline Wow & 220 & 0.18 & 0.83 & 0 & 0 & 15 \\
\hline Sorry & 15 & 0.01 & 0.21 & 0 & 0 & 6 \\
\hline Anger & 22 & 0.02 & 0.52 & 0 & 0 & 18 \\
\hline Comments & 639 & 0.51 & 2.47 & 0 & 0 & 54 \\
\hline Shares & 1375 & 1.10 & 4.50 & 0 & 0 & 135 \\
\hline
\end{tabular}


INTERNATIONAL JOURNAL OF ENTREPRENEURIAL KNOWLEDGE

Issue 1, volume 8, ISSN 2336-2960 (Online)

www.ijek.org

(Source: Authors' Calculations)

Shallow involvement of the highest form is also confirmed by Table 5, which shows average proportions of occurrence of individual forms of engagement per post. Surprisingly, results signify that Video type posts are not favorite (Mean number of interactions per video post=12.66).

Table 5 Interactions per post type (untransformed data)

\begin{tabular}{||c|c|c|c|c||}
\hline $\begin{array}{c}\text { ANALYSIS } \\
\text { COLUMNS }\end{array}$ & $\begin{array}{c}\text { LINK } \\
(\text { MEAN) }\end{array}$ & $\begin{array}{c}\text { PHOTO } \\
\text { (MEAN) }\end{array}$ & $\begin{array}{c}\text { STATUS } \\
\text { (MEAN) }\end{array}$ & $\begin{array}{c}\text { VIDEO } \\
\text { (MEAN) }\end{array}$ \\
\hline Likes & 11.07 & 22.23 & 6.65 & 10.44 \\
\hline Love & 1.26 & 1.86 & 0.37 & 0.77 \\
\hline Haha & 0.00 & 0.07 & 0.05 & 0.08 \\
\hline Wow & 0.04 & 0.19 & 0.05 & 0.05 \\
\hline Sorry & 0.00 & 0.01 & 0.02 & 0.00 \\
\hline Anger & 0.00 & 0.02 & 0.05 & 0.00 \\
\hline Comments & 0.19 & 0.51 & 0.77 & 0.34 \\
\hline Shares & 2.30 & 1.07 & 1.26 & 0.97 \\
\hline Total & 14.85 & 25.96 & 9.21 & 12.66 \\
\hline
\end{tabular}

(Source: Authors' Calculations)

According to $\mathrm{H} 2$, diverse content types (status, photo, video, link) differ in customer engagement (CE). As Table 6 presents, the differences between some of the means in according to post types are statistically significant $(\mathrm{p}=0.0009)$, and thus the results support $\mathrm{H} 2$.

Table 6 Interactions per post type (untransformed data)

\begin{tabular}{||c|c|c|c|c|c||}
\hline \hline LEVEL & NUMBER & MEAN & $\begin{array}{c}\text { STD } \\
\text { ERROR }\end{array}$ & F RATIO & PROB > F \\
\hline link & 27 & 4.78859 & 0.33716 & 5.5424 & 0.0009 \\
\hline photo & 980 & 4.90475 & 0.05596 & & \\
\hline status & 49 & 4.27291 & 0.25028 & & \\
\hline video & 56 & 4.09421 & 0.23412 & & \\
\hline
\end{tabular}

(Source: Authors' Calculations)

We also used the Tukey Simultaneous Test for finding differences in customer engagement according to post types. As Table 7 presents, the only difference in photo-video customer engagement (CE) is statistically significant $(\mathrm{p}-\mathrm{Value}=0.0044)$.

Table 7 Tukey Simultaneous Test for Differences of Means - customer engagement according to post type (log-transformed data)

\begin{tabular}{|l|l|l|l|l|l|}
\hline LEVEL & DIFFERENCE & STD ERR & LOWER & UPPER CL & P-VALUE \\
\hline
\end{tabular}


INTERNATIONAL JOURNAL OF ENTREPRENEURIAL KNOWLEDGE

Issue 1, volume 8, ISSN 2336-2960 (Online)

www.ijek.org

\begin{tabular}{||c|c|c|c|c|c||}
\hline \hline $\begin{array}{c}\text { photo - } \\
\text { video }\end{array}$ & 0.8105354 & 0.2407111 & 0.191186 & 1.429884 & 0.0044 \\
\hline link - video & 0.694372 & 0.4104748 & -0.361778 & 1.750522 & 0.3285 \\
\hline $\begin{array}{c}\text { photo - } \\
\text { status }\end{array}$ & 0.6318432 & 0.2564602 & -0.028028 & 1.291715 & 0.0663 \\
\hline link - status & 0.5156799 & 0.4199042 & -0.564732 & 1.596092 & 0.6091 \\
\hline $\begin{array}{c}\text { status - } \\
\text { video }\end{array}$ & 0.1786921 & 0.3427093 & -0.703098 & 1.060482 & 0.9539 \\
\hline photo - link & 0.1161634 & 0.3417772 & -0.763229 & 0.995555 & 0.9865 \\
\hline
\end{tabular}

(Source: Authors' Calculations)

To build the model for $\mathrm{H} 3$, we started with all explanatory variables (status, photo, video, link). Regression analysis showed that there is a linear relationship which could be described with formula as follows: $2.7194522+0.436169707 * \log$ (TextLength) (Whole model $\mathrm{p}$-value $<0.0001$, Intercept $\mathrm{p}$-value $<0.0001, \log ($ TextLength) p-value <0.0001). Results suggest, to reject H3 because the longer the text section is, the higher engagement interactions it has. Because of the low RSquare value (0.02842), we tried to optimize this model by examining each type of post's relationship. We found no significant linear relationships between the length of the text part and customer engagement in status, video, and link post type. In photo type post, there was significant linear relationship, which could be described with formula as follows: 3.0082836911+0.3864735001* $\log ($ TextLength) (Whole model pvalue $<0.0001$, Intercept p-value $<0.0001, \log ($ TextLength $)$ p-value $<0.0001$, RSquare value $=0.021607)$.

\section{CONCLUSIONS}

Social media might represent the most considerable social innovation/revolution in the history of communication, fundamentally altering how humans communicate, and the practice of public relations, journalism, advertising, marketing, and business (Kent et al., 2020). They have become an integral part of the marketing strategy (Rehman et al., 2020) and bring companies a platform for communicating, sharing ideas, showcasing their creative works, proving their talent, and finding new people of the same interest (Smruthi et al., 2019). Social networks thus restructuring communication and interactions between individuals, communities, and businesses (Hu et al., 2019).

Today's social networks allow customers to react to new content in numerous ways. For example, a customer, impressed by post, might react to it by liking it and then sharing it forward to her friends (Rakoczy et al., 2019). These reactions, customer engagement with companies' posts, affect the extent of the messages spreading. The more interesting and engaging the message, the better it spreads. Therefore, companies must take an active approach to social network content management and look for ways to increase customer engagement (CE).

The study aimed to examine content strategy on coffee shops' Facebook brand-fan pages and its impact on customer engagement. We specifically focused on the differences between the length of the text part of posts, diverse content types increasing customer engagement (CE)., and impact of text the length on increasing customer engagement (CE).

Firstly, we found statistically significant differences between text length and post type (status, photo, video, link $)(p=0.0007)$. In further examining these differences, we found that there exist statistically significant differences only between photo and status types of posts $(p-V a l u e=0.0009)$. Unexpected, in this context, is the finding that the text part of the photo post is longer (Mean=178.16 characters) than 


\section{INTERNATIONAL JOURNAL OF ENTREPRENEURIAL KNOWLEDGE}

Issue 1, volume 8, ISSN 2336-2960 (Online)

www.ijek.org

in status (Mean=104.19 characters). Secondly, we confirmed that also, the content type differs in customer engagement $(\mathrm{CE})(\mathrm{p}=0.0009)$. However, we did not find statistically significant differences between link - video, photo - status, link - status, status - video, photo - link. The differences existed only between photo and status types of posts $(p-V a l u e=0.0009)$. Thirdly, the results of linear regression were unable to support the hypothesis that the shortest length of the text leads to higher customer engagement (CE). The study also revealed an overall weak coffee shops' content strategy. Coffee shops are unable to produce social network content with a high degree of customer engagement at all, nor with a greater extent of customer involvement (comments, shares).

Although the study extends the research on customer engagement (CE) and expands the knowledge about Facebook coffee companies' content strategy, some limitations should also be discussed. First of all, it should be noted that we did not have data that would distinguish the extent to which customer engagement (CE) has resulted as a consequence of organic or paid reach of posts. However, given that we have been researching a relatively long period, we believe that companies' approach could have been similar and thus did not affect the results much. Secondly, the examined coffee-shops represented only small businesses. The generalizability of the results for other sizes of companies must, therefore, be the subject of further research.

In future research, it would be useful to address the limitations of this research and other content strategy elements, such as customer engagement (CE), according to the types of appeals or images.

\section{REFERENCES}

Avnet, T., \& Higgins, E. T. (2018). How Regulatory Fit Affects Value in Consumer Choices and Opinions. Journal of Marketing Research, 43(1), 1-10. doi:10.1509/jmkr.43.1.1

Banerjee, S., \& Chua, A. Y. K. (2019). Identifying the antecedents of posts' popularity on Facebook Fan Pages. Journal of Brand Management, 26(6), 621-633. doi:10.1057/s41262-019-00157-7

Bitiktas, F., \& Tuna, O. (2020). Social media usage in container shipping companies: Analysis of Facebook messages. Research in Transportation Business and Management. doi:10.1016/j.rtbm.2020.100454

Brodie, R. H., L.D., Ilic, A. \& Juric, B. . (2011). Customer engagement: Conceptual domain, fundamental propositions, and implications for research. Journal of Service Research, , 14(3), 252.

Chan, T. K. H., Zheng, X., Cheung, C. M. K., Lee, M. K. O., \& Lee, Z. W. Y. (2014). Antecedents and consequences of customer engagement in online brand communities. Journal of Marketing Analytics, 2(2), 81-97. doi:10.1057/jma.2014.9

Chiang, I. P., Tu, S. E., \& Wang, L. H. (2018). Exploring the social marketing impacts of virtual brand community engagement. Contemporary Management Research, 14(2), 143-164. doi:10.7903/cmr.18086

Cho, M., Schweickart, T., \& Haase, A. (2014). Public engagement with nonprofit organizations on Facebook. Public Relations Review, 40(3), 565-567. doi:10.1016/j.pubrev.2014.01.008

Cooper, T., Stavros, C., \& Dobele, A. R. (2019). The levers of engagement: an exploration of governance in an online brand community. Journal of Brand Management, 26(3), 240-254. doi:10.1057/s41262-018-0132-2

De Vries, N. J., \& Carlson, J. (2014). Examining the drivers and brand performance implications of customer engagement with brands in the social media environment. Journal of Brand Management, 21(6), 495-515. doi:10.1057/bm.2014.18

Dijkmans, C., Kerkhof, P., \& Beukeboom, C. J. (2015). A stage to engage: Social media use and corporate reputation. Tourism Management, 47, 58-67. doi:10.1016/j.tourman.2014.09.005

Eigenraam, A. W., Eelen, J., van Lin, A., \& Verlegh, P. W. J. (2018). A Consumer-based Taxonomy of Digital Customer Engagement Practices. Journal of Interactive Marketing, 44, 102-121. doi:10.1016/j.intmar.2018.07.002 


\section{INTERNATIONAL JOURNAL OF ENTREPRENEURIAL KNOWLEDGE}

Issue 1, volume 8, ISSN 2336-2960 (Online)

www.ijek.org

Ersoy, A. B., Zaim, H., Keceli, Y., \& Kurtishi-Kastrati, S. (2018). Brand ethics and social media engagement. International Journal of Foresight and Innovation Policy, 13(1-2), 14-32. doi:10.1504/IJFIP.2018.095855

Gruss, R., Kim, E., \& Abrahams, A. (2020). Engaging Restaurant Customers on Facebook: The Power of Belongingness Appeals on Social Media. Journal of Hospitality and Tourism Research, 44(2), 201228. doi:10.1177/1096348019892071

Harmeling, C. M., Moffett, J. W., Arnold, M. J., \& Carlson, B. D. (2016). Toward a theory of customer engagement marketing. Journal of the Academy of Marketing Science, 45(3), 312-335. doi:10.1007/s11747-016-0509-2

Hollebeek, L. (2011). Exploring customer brand engagement: definition and themes. Journal of Strategic Marketing, 19(7), 555-573. doi:10.1080/0965254x.2011.599493

Hollebeek, L. D. (2011). Demystifying customer brand engagement: Exploring the loyalty nexus. Journal of Marketing Management, 27(7-8), 785-807. doi:10.1080/0267257x.2010.500132

Hollebeek, L. D., Conduit, J., \& Brodie, R. J. (2016). Strategic drivers, anticipated and unanticipated outcomes of customer engagement. Journal of Marketing Management, 32(5-6), 393-398. doi:10.1080/0267257x.2016.1144360

Hu, H. W., Hsu, K. S., Lee, C., Hu, H. L., Hsu, C. Y., Yang, W. H., . . Chen, T. A. (2019) KeywordDriven Depressive Tendency Model for Social Media Posts. In: Vol. 354 (pp. 14-22).

Javornik, A., \& Mandelli, A. (2012). Behavioral perspectives of customer engagement: An exploratory study of customer engagement with three Swiss FMCG brands. Journal of Database Marketing and Customer Strategy Management, 19(4), 300-310. doi:10.1057/dbm.2012.29

Kaplan, A. M., \& Haenlein, M. (2010). Users of the world, unite! The challenges and opportunities of Social Media. Business Horizons, 53(1), 59-68. doi:10.1016/j.bushor.2009.09.003

Kent, M. L., \& Li, C. (2020). Toward a normative social media theory for public relations. Public Relations Review, 46(1). doi:10.1016/j.pubrev.2019.101857

Kim, B., Yoo, M., \& Yang, W. (2020). Online Engagement Among Restaurant Customers: The Importance of Enhancing Flow for Social Media Users. Journal of Hospitality and Tourism Research, 44(2), 252-277. doi:10.1177/1096348019887202

Kim, E., \& Tang, R. (2016). Rectifying Failure of Service: How Customer Perceptions of Justice Affect Their Emotional Response and Social Media Testimonial. Journal of Hospitality Marketing \& Management, 25(8), 897-924. doi:10.1080/19368623.2016.1149537

Kujur, F., \& Singh, S. (2017). Engaging customers through online participation in social networking sites. Asia Pacific Management Review, 22(1), 16-24. doi:10.1016/j.apmrv.2016.10.006

Kujur, F., \& Singh, S. (2020). Visual communication and Consumer-Brand relationship on Social Networking Sites - Uses \& Gratifications Theory Perspective. Journal of Theoretical and Applied Electronic Commerce Research, 15(1), 30-47. doi:10.4067/S0718-18762020000100104

Kumaresan, A. (2014) Increasing User Engagement Using Innovative Poll First Content Delivery Method. In: Vol. 185 LNBIP (pp. 167-176).

Miller, A. R., \& Tucker, C. (2013). Active Social Media Management: The Case of Health Care. Information Systems Research, 24(1), 52-70. doi:10.1287/isre.1120.0466

Newman, N., Fletcher, R., Kalogeropoulos, A., \& Nielsen, R. K. (2019). Reuters Institute Digital News Report 2019. Oxford, UK: Reuters Institute for the Study of Journalism.

Rakhmawati, N. A., \& Hanindito, D. (2018). An integrated Assessment System of Citizen Reaction towards Local Government Social Media Accounts. Journal of Information Technology Management, 10(3), 1-19. doi:10.22059/JITM.2019.283221.2367

Rakoczy, M. E., Bouzeghoub, A., Wegrzyn-Wolska, K., \& Gancarski, A. L. (2019) Exploring Interactions in Social Networks for Influence Discovery. In: Vol. 354 (pp. 23-37).

Ravi, K., \& Ravi, V. (2015). A survey on opinion mining and sentiment analysis: Tasks, approaches and applications. Knowledge-Based Systems, 89, 14-46. doi:10.1016/j.knosys.2015.06.015 
INTERNATIONAL JOURNAL OF ENTREPRENEURIAL KNOWLEDGE

Issue 1, volume 8, ISSN 2336-2960 (Online)

www.ijek.org

Rehman, Z. U., Baharun, R., \& Salleh, N. Z. M. (2020). Antecedents, consequences, and reducers of perceived risk in social media: A systematic literature review and directions for further research. Psychology and Marketing, 37(1), 74-86. doi:10.1002/mar.21281

Rietveld, R., van Dolen, W., Mazloom, M., \& Worring, M. (2020). What You Feel, Is What You Like Influence of Message Appeals on Customer Engagement on Instagram. Journal of Interactive Marketing, 49, 20-53. doi:10.1016/j.intmar.2019.06.003

Siyam, N., Alqaryouti, O., \& Abdallah, S. (2020). Mining government tweets to identify and predict citizens engagement. Technology in Society, 60. doi:10.1016/j.techsoc.2019.101211

Smruthi, M., \& Harini, N. (2019). A hybrid scheme for detecting fake accounts in facebook. International Journal of Recent Technology and Engineering, 7(5), 213-217. Retrieved from https://www.scopus.com/inward/record.uri?eid=2-s2.085067030422\&partnerID $=40 \& \mathrm{md} 5=790 \mathrm{a} 6276 \mathrm{~d} 79 \mathrm{da} 6 \mathrm{bcdee} 6 \mathrm{c} 2 \mathrm{~d} 4 \mathrm{cf0d} 691 \mathrm{f}$

Swani, K., Brown, B. P., \& Milne, G. R. (2014). Should tweets differ for B2B and B2C? An analysis of Fortune 500 companies' Twitter communications. Industrial Marketing Management, 43(5), 873-881. doi:https://doi.org/10.1016/j.indmarman.2014.04.012

Thongmak, M. (2015) Engaging Facebook users in brand pages: Different posts of marketing-mix information. In: Vol. 208 (pp. 299-308).

Tulu, D. T. (2017). Should online social Medias (OSMs) be banned at work? The impact of social Medias on employee productivity in Ambo University, a case study. Research in International Business and Finance, 42, 1096-1102. doi:10.1016/j.ribaf.2017.07.044

Vaičiukynaite, E., \& Gatautis, R. (2018). How hotel companies can foster customer sociability behaviour on facebook? Journal of Business Economics and Management, 19(4), 630-647. doi:10.3846/jbem.2018.5691

Zeng, X., McKenna, B., Richter, S., \& Cai, W. (2019) How social media can afford engagement processes. In: Vol. 341 (pp. 272-279).

\section{BRIEF DESCRIPTION OF AUTHOR/AUTHORS:}

\section{Lucia Ferencakova, Mgr.}

Department of Marketing, Faculty of Management, Comenius University in Bratislava, Odbojarov 10, 82005 Bratislava, Slovak Republic, https://www.fm.uniba.sk, lucia.ferencakova@,fm.uniba.sk.

Lucia Ferencakova is a doctoral student. She focuses his research efforts on the adoption of social media in SMEs.

\section{Krzysztof Gajdka, doc. Mgr., Ph.D., MBA.}

Department of Marketing, University of Entrepreneurship and Law Prague, Vltavska 585/14, 15000 Praha 5, Czech Republic, https://www.vspp.cz/, krzysztof.gajdka@,vspp.cz.

In addition to his academic activities, the associate professor Gajdka works as an expert in the field of media communication. He is actively involved in advising on external political and electoral media communication for the most important Polish political entities.

Vaclav Netek, doc. Ing., CSc.

Department of Marketing, University of Entrepreneurship and Law Prague, Vltavska 585/14, 15000 Praha 5, Czech Republic, https://www.vspp.cz/, vaclav.netek@,vspp.cz.

Associate professor Netek focuses his research activities in the area of industrial marketing and economics and management of small and medium-sized enterprises in the field of services.

Pavel Kapoun, Mgr., Ph.D. 
INTERNATIONAL JOURNAL OF ENTREPRENEURIAL KNOWLEDGE

Issue 1, volume 8, ISSN 2336-2960 (Online)

www.ijek.org

Department of Marketing, University of Entrepreneurship and Law Prague, Vltavska 585/14, 15000 Praha 5, Czech Republic, https://www.vspp.cz/, pavel.kapoun@vspp.cz.

Doctor Kapoun is a specialist in the field of public relations, media and information education, marketing and communication. He has extensive experience in the use of information technology. 